Unterricht in Spanien und Deutschland / [W. Altmann]. - Berlin: Frey, 2004. - S. 11-40. 3. Hallet W. Bilingualer Unterricht: Fremdsprachig denken, lernen und Handeln / W. Hallet // Der fremdsprachliche Unterricht Englisch. - 2005. - № 78. - S. 2-13. 4. Hallet W. Ein didaktisches Modell für den bilingualen Sachfachunterricht: The Bilingual Triangle/ W. Hallet// Neusprachliche Mitteilungen aus Wissenschaft und Praxis. - 1999. - № 52. - S. 23-27. 5. Königs F. G. Mehrsprachigkeit? Ja, aber..../ F. G. Königs // Französisch heute. - 2002. - № 33/1. - S. 22-33. 6. Krechel H.-J. Ausbildung von Fremdsprachenlehrern in der zweiten Phase / H.-J. Krechel // Handbuch Fremdsprachenunterricht / [K.-R. Bausch, H. Christ, H.-J. Krumm. - 5. Auflage. Tübingen; Basel: A. Francke, 2007. - S. 482-486. 7. Sekretariat der Ständigen Konferenz der Kultusminister der Länder in der Bundesrepublik Deutschland / Konzepte für den bilingualen Unterricht: Erfahrungsbericht und Vorschläge zur Weiterentwicklung: (Bericht vom Schulausschusses von 10.04.2006) [Електронний ресурс]. - Режим доступу: http://www.kmk.org/fileadmin/veroeffentlichungen_beschluesse/2006/2006_04_10Konzepte-bilingualer- Unterricht.pdf. - Заголовок з екрана. 8. Wolff D. Zur Ausbildung von Lehrerinnen und Lehrern für mehrsprachige Bildungsgänge / D. Wolff / Bilingualer Sachfachunterricht: Didaktik, Lehrer-, Lernerforschung und Bildungspolitik zwischen Theorie und Empirie / [S. Breidbach, G. Bach, D. Wolff]. - Frankfurt/a/M.; Berlin; Bern; Brusseles; New York; Oxford; Wien: Peter Lang, 2002. - S. 253-267.

Олена Гнізділова

\title{
ЗМІСТ І НАПРЯМИ ДІЯЛЬНОСТІ НАУКОВОЇ ШКОЛИ ПРОФЕСОРА Н. В. ГАВРИШ
}

Гнізділова О.А. Зміст і напрями діяльності наукової школи професора Н. В. Гавриш.

У статті висвітлено основні здобутки представників наукової школи доктора педагогічних наук, професора, завідувача кафедри дошкільної та початкової освіти Державного закладу «Луганський національний університет імені Тараса Шевченка» Наталії Василівни Гавриш. Головну увагу зосереджено на розкритті основних граней iï науково-педагогічної діяльності як автора численних наукових публікацій, наукового керівника дисертаційних праць, редактора фахових наукових збірників i часописів, члена спеціалізованих учених рад, лідера науковопедагогічної школи «Психолого-педагогічні та соціальні аспекти дошкільної і початкової освіти».

Ключові слова: наукова школа, науковець, учні, науковий лідер, науководослідницька діяльність, тематика наукових пошуків.

Гниздилова О. А. Содержание и направления деятельности научной школы профессора Н. В. Гавриш.

В статье освещены основные достижения представителей научной школы доктора педагогических наук, профессора, заведующего кафедрой дошкольного и начального образования Государственного учреждения «Луганский национальный университет имени Тараса Шевченко» Наталии Васильевны Гавриш. Главное внимание сосредоточено на раскрытии основных граней ее научно-педагогической деятельности как автора многочисленных научных публикаций, научного руководителя диссертационных работ, редактора профессиональных научных сборников и журналов, члена диссертационных советов, лидера научно- 
педагогической школы «Психолого-педагогические и социальные аспекты дошкольного и начального образования».

Ключевые слова: научная школа, ученый, ученики, научный лидер, научноисследовательская деятельность, тематика научных поисков.

Gnizdilova O. A The content and activities of the scientific school of Professor N. Gavrish.

The article highlights the main achievements of members of the scientific school doctor of pedagogical sciences, professor, head of the Department of Early Childhood and Elementary Education State establishment of «Luhansk National Pedagogical University named after Taras Shevchenko» Natalia Vasylivna Gavrish. The main attention is focused on revealing the fundamental facets of scientific and educational activities as an author of numerous scientific publications of the supervisor of dissertation research, professional scientific editor of anthologies and journals, a member of the specialized scientific councils, the leader of the scientific and pedagogical school «psycho-pedagogical and social aspects of preschool and elementary education».

Key words: scientific school, scientist, students, academic leader, research activities, the subject of scientific research.

Ефективність наукового прогресу залежить від кваліфікаційного ресурсу кадрового наукового потенціалу, досконалої і розвиненої інфраструктури, що постійно поповнюється висококваліфікованими працівниками. Це позначається на неухильному зростанні ролі наукової спільноти, яка формує та розвиває наукове знання, сприяє його утвердженню в конкурентному науковому середовищі, поширює та впроваджує отримані наукові результати. Однією з провідних форм творчої колективної співпраці науковців, їх кооперації у процесі наукового пошуку $\epsilon$ наукова школа, яка транслює, окрім суто наукового змісту, культурні норми i цінності від старшого покоління до молодшого. Тому значення наукової школи як інноваційного центра модернізації освіти зростає.

За роки державності України сформувалися потужні науково-педагогічні школи, лідерами-засновниками яких багато зроблено для вироблення і поширення педагогічного знання, здійснення наукових досліджень у галузі освіти, активізації інноваційної діяльності педагогів освітніх установ, отримання конкретних результатів у практиці діяльності навчальних закладів.

Аналіз наукової літератури свідчить, що останнім часом педагогічна наука збагатилася численними дослідженнями, у яких автори (А. Бойко, О. Дубасенюк, Л. Зеленська, М. Лещенко, І. Сіра, Л. Попова та ін.) розкривають генезу окремих науково-педагогічних шкіл України, з позицій персоніфікації аналізують діяльність їх наукових лідерів. У монографії та низці наукових публікацій ми започаткували дослідження авторського внеску лідерів-засновників науково-педагогічних шкіл України [5]. Наразі аналіз багатогранної діяльності професора Н. Гавриш та дочірньої наукової школи академіка А. Богуш.

Meта cmammi полягає у визначенні напрямів науково-педагогічної діяльності Н. Гавриш як лідера наукових розробок і пошуків у галузі педагогіки i лінгводидактики, здійсненні аналізу здобутків представників її наукової школи.

Для того щоб розкрити витоки становлення іiі науково-педагогічної школи, концентруємо увагу на вивченні життєвих реалій особистості науковця, що сприяли iii науковому розвитку. Свою наукову діяльність Н. Гавриш розпочала у 
Слов'янському державному педагогічному інституті, де працювала викладачем кафедри дошкільної педагогіки (1984-2003 рр.). Після успішного закінчення аспірантури (м. Москва, НДІ дошкільного виховання АПН СРСР) у 1991 році захистила дисертацію на здобуття наукового ступеня кандидата педагогічних наук на тему «Формування образності мовлення старших дошкільників у процесі навчання рідної мови». У 1994 році їй присвоєно вчене звання доцента.

У 1998-2001 рр. навчалася в докторантурі Південноукраїнського державного педагогічного університету імені К. Д. Ушинського. Дисертаційне дослідження 3 теми «Розвиток мовленнєвотворчої діяльності в дошкільному дитинстві» виконане як результат співпраці 3 науковим консультантом доктором педагогічних наук, професором, дійсним членом НАПН України А. Богуш. Успішний захист докторської дисертації відбувся у стінах Національного педагогічного університету імені М. П. Драгоманова у квітні 2002 року.

У дисертації Н. Гавриш представлено концептуально новий підхід до розв'язання проблеми розвитку мовленнєвотворчої діяльності дітей дошкільного віку, що розглядається як стрижень розвитку творчих здібностей дітей у різних видах художньої діяльності. Уперше мовленнєвотворча діяльність вивчалася не тільки в межах організованого навчання, а й у ситуації ініціативної словесної творчості. Мовленнєвотворча діяльність дошкільнят розглядається як феномен мовленнєвої культури, що відбиває рівень психічного розвитку, мовленнєвої компетентності, внутрішнього, духовного і душевного стану, вираження переваг та інтересів дітей, а також як важливий та ефективний засіб їхнього художньоестетичного, інтелектуально-творчого розвитку, формування креативного начала кожної особистості. У процесі дослідження було систематизовано й узагальнено дані з типології мовленнєвотворчої діяльності дошкільнят у ситуаціях спеціального навчання та ініціативної творчості [4, с. 38].

Виокремлено критерії оцінки і показники рівня розвитку мовленнєвотворчої діяльності, 3-поміж яких: мовленнєва компетентність, елементарна літературознавча обізнаність, креативність, експресивність, ставлення дитини до мовленнєвотворчої діяльності. Це дозволило встановити три основних рівні розвитку мовленнєвотворчої діяльності: репродуктивний, на якому відбувається лише відтворення норм мовленнєвої культури за незначної частки творчих дій; нормативно-адаптивний, пов'язаний 3 узагальненим наслідуванням, яке виражається в усвідомленому сприйнятті зразка, «норми», у самостійному використанні знайомих дітям способів мовленнєвих дій у різних ситуаціях; творчий, коли вміння стають узагальненими і становлять вихідну позицію для творчості, діти починають застосовувати свої знання, вміння в нестандартних ситуаціях [4, с. 38-39].

Результати проведеного дослідження дозволили авторові дійти висновків, що найбільш ефективною для розвитку мовленнєвотворчої діяльності $\epsilon$ розвивальна формула навчально-освітнього процесу, така його організація, в якій пріоритетним $\epsilon$ розвиток здібностей, а знання постають засобом цього розвитку; ступінь реалізації мовленнєвотворчої діяльності $\epsilon$ мірою ефективності гармонійного розвитку креативних здібностей, розкриття творчих потенцій дітей, збагачення їх художньоестетичного розвитку на етапі дошкільного дитинства; в ініціативну мовленнєвотворчу діяльність дитина трансформує отримані уявлення про мистецькі твори, засоби мовленнєвої образності, елементарні літературознавчі знання [4, с. 39]. 
Н. Гавриш довела, що врахування і реалізація сукупності чинників, 3-поміж яких: спеціальна організація освітнього процесу, шо грунтується на особистісно зорієнтованій моделі взаємодії його учасників, створеній сприятливій атмосфері; система мовленнєвої роботи, спрямована на поступовий перехід дитини від репродуктивних до мовленнєвотворчих дій; інтеграція різних видів дитячої творчості (образотворчої, музично-ритмічної, театральної) - створюють умови, сприятливі для розвитку мовленнєвотворчої діяльності дітей у дошкільному закладі [4, с. 38-39].

Наступний етап творчого шляху i професійного зростання Н. Гавриш пов'язаний із Луганським національним університетом імені Тараса Шевченка, де вона 3 вересня 2003 року обіймає посаду завідувача кафедри дошкільної та початкової освіти. Учене звання професора цієї кафедри отримала у 2004 році. Цього ж року вона обирається членом-кореспондентом Міжнародної академії наук педагогічної освіти.

Доктор педагогічних наук, професор Н. Гавриш у 2003 р. заснувала наукову школу «Психолого-педагогічні та соціальні аспекти дошкільної і початкової освіти». Основна тематика їі дослідницьких пошуків та членів наукової школи пов'язана 3 розвитком дошкільної педагогіки та лінгводидактики, дослідженням питань розвитку мовлення дітей на різних вікових етапах дитинства, специфіки педагогічної діяльності, спрямованої на формування мовних навичок у дітей, вивченням засобів, форм, методів і прийомів навчання мови дітей дошкільного віку. Загалом під науковим керівництвом професора Н. Гавриш захищено понад 15 кандидатських дисертацій.

Дослідження 3 розвитку мовленнєвотворчої діяльності, розпочате нею, отримало продовження в роботах ï аспірантів Н. Водолаги, яка вивчала специфіку навчання розповідання дітей старшого дошкільного віку в театральній діяльності (2001) [2], О. Саприкіної, яка узагальнила шляхи та засоби розвитку активного мовлення дітей третього року життя в художньо-продуктивній діяльності (2008) [13] та Г. Лопатіної, що розробила й апробувала методику навчання діалогічного мовлення дітей молодшого дошкільного віку (2012) [7].

3-поміж досягнень наукової школи професора Н. Гавриш $\epsilon$ розроблення комплексної соціально-педагогічної тематики «Діти і соціум». Першою роботою в цьому напрямку стала кандидатська дисертація С. Курінної «Особливості соціалізації дітей шести - семи років у різних умовах життєдіяльності» (2004) [6]. Дослідження цієї тематики продовжили аспіранти професора Н. Гариш Л. Варяниця (2005) [1] та О. Малахова (2007) [10], які дослідили дитячу субкультуру в сучасному соціумі та педагогічні умови соціалізації молодших школярів у взаємодії 3 однолітками. Предметом подальшого наукового пошуку учнів школи професора Н. В. Гавриш стало дослідження організації соціально-педагогічної підтримки батьків дітей раннього віку з особливими потребами (I. Макаренко, 2009) [9].

2006 року побачила світ колективна монографія «Діти і соціум», підготовлена за науковою редакцією А. Богуш та Н. Гавриш і привячена висвітленню широкого кола теоретико-методологічних проблем вивчення сучасного дитинства, дитячої субкультури, формування соціальної компетентності дітей дошкільного та молодшого шкільного віку.

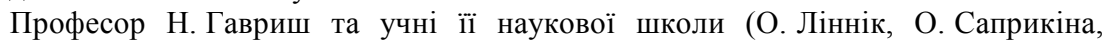
С. Курінна, Н. Бушуєва, Л. Варяниця, О. Малахова, А. Сазонова) є співавторами колективної монографії «Дитина - педагог: сучасний погляд» (2010р.), у якій ними 
розглянуто загальні підходи до вивчення проблем сучасного дитинства, особливості набуття дітьми різноманітних компетентностей у процесі дошкільної та початкової шкільної освіти. Ця робота відображає результати наукових досліджень аспірантів професора Н. Гавриш.

За останні десять років представниками наукової школи та особисто професором Н. Гавриш досліджувалися різні аспекти дошкільної і початкової освіти: формування первинного економічного досвіду дітей старшого дошкільного віку (А. Сазонова, 2007 р.); дидактичні умови розвитку допитливості учнів першого класу (О. Ліннік, 2007 р.); педагогічні умови формування навчальної мотивації дітей шестирічного віку (Н. Бушуєва, 2008 р.); формування музично-естетичних смаків студентів педагогічних університетів у процесі художньо-творчої діяльності (О. Берестенко, 2008 р.); підготовка майбутніх вихователів дошкільного закладу до формування основ комп'ютерної грамоти в дітей старшого дошкільного віку (С. Дяченко, 2009 р.); організаційно-педагогічні умови управління якістю роботи дошкільного навчального закладу (О. Янко, 2009 р.); формування готовності до професійного саморозвитку майбутніх учителів початкових класів (А. Бистрюкова, 2009 р.); формування контрольно-оцінних умінь у молодших школярів (В. Глазова, 2012 р.); виховання гуманістичних цінностей у студентів педагогічних коледжів у процесі волонтерської діяльності (Т. Ткачук, 2013 р.).

Отже, представники наукової школи Н. Гавриш досліджують теоретикометодичні проблеми дошкільної та вишівської освіти, соціально-педагогічні аспекти виховання і розвитку дітей дошкільного і молодшого шкільного віку, особливості набуття дітьми різноманітних компетентностей у процесі дошкільної та початкової шкільної освіти, розробляють інноваційні навчально-виховні технології.

Нині доробок Н. Гавриш становить понад 140 наукових та навчальнометодичних праць. 3-під пера дослідниці побачили світ монографії, навчальні посібники, підручники, методичні рекомендації, наукові статті. Найбільш значущими 3-поміж них є такі публікації: «Художнє слово та дитяче мовлення» (1998), «Розвиток мовлення в дошкільному віці» (2001), «Розвиток мовленнєвотворчої діяльності в дошкільному дитинстві» (2001), «Методика розвитку зв'язного мовлення дітей дошкільного віку» (2005), «Теорія і практика лексичного розвитку дошкільників» (2009) тощо. Н. Гавриш є співавтором навчальної програми курсу «Дошкільна лінгводидактика» для студентів вищих педагогічних навчальних закладів, програми навчання та виховання дітей у дошкільних навчальних закладах «Дитина в дошкільні роки», одним із розробників коментаря до Базового компонента дошкільної освіти.

Професійно новаторськими є підручники і навчальні посібники Н. Гавриш для студентів вищих педагогічних навчальних закладів і вихователів сучасних ДНЗ «Лінгводидактика в сучасних закладах освіти» (2000), «Знакомим дошкольников с литературой» (2002), «Дошкільна лінгводидактика: теорія і методика навчання дітей рідної мови» (2007), «Сучасне заняття в дошкільному закладі» (2007), «Теорія і методика розвитку мовлення дітей раннього віку» (2009), написані одноосібно або у співавторстві з колегами. При цьому кількість опублікованих наукових праць (монографій, підручників та посібників із грифом $\mathrm{MOH}$, статей у фахових виданнях) є критерієм дієвості та результативності наукової школи професора Н. Гавриш.

Суттєве місце у іï професійній діяльності посідає підвищення професійної майстерності педагогів дошкільної та початкової освіти в різних областях України: 
дослідниця постійно проводить авторські науково-методичні семінари, активно працює на курсах підвищення кваліфікації [8].

Н. Гавриш є членом редакційної колегії фахових науково-педагогічних видань «Гуманізація навчально-виховного процесу» Державного вищого навчального закладу «Донбаський державний педагогічний університет», «Вісник Луганського національного університету імені Тараса Шевченка» та Всеукраїнських журналів «Дошкільне виховання» й «Учитель початкової школи».

Ще одним важливим напрямком наукової діяльності професора Н. Гавриш $\epsilon$ участь у роботі спеціалізованих учених рад. Вона $є$ членом спеціалізованих учених рад Д3 «Луганський національний педагогічний університет імені Тараса Шевченка» та Південноукраїнського державного педагогічного університету імені К. Д. Ушинського. Науковець неодноразово виступала офіційним опонентом на захистах кандидатських і докторських дисертацій.

За плідну наукову та навчально-методичну діяльність вона отримала індивідуальну нагороду - нагрудний знак «Відмінник освіти України» (2001), нагороджена грамотами Луганського національного педагогічного університету імені Тараса Шевченка, Головного управління освіти Луганської обласної державної адміністрації (2004), а також Почесною грамотою Міністерства освіти і науки України (2005p.) [3; 8]. Указом Президента України від 4 жовтня 2013 р. № 543/2013 Державну премію України в галузі освіти у номінації «Дошкільна і позашкільна освіта» присуджено А. Богуш та Н. Гавриш за цикл наукових праць «Дошкільна освіта: наука, теорія, практика» [11].

Отже, наукова школа професора Н. Гавриш, спрямована на пізнання теоретико-методичних і соціально-педагогічних проблем дошкільної і початкової освіти, робить вагомий внесок у розвиток дошкільної педагогіки та лінгводидактики. Дослідження, які проводяться в межах наукової школи, характеризуються: цілісністю й системністю пізнання специфіки формування способів мовленнєвої діяльності та навчання дітей раннього, дошкільного і молодшого шкільного віку мови, дослідження методики й інноваційних технологій розвитку мовлення дошкільників, вивчення особливостей набуття дітьми різноманітних компетентностей у процесі дошкільної та початкової шкільної освіти; єдністю теорії і практики у пізнанні проблем сучасного дитинства. Подальше розроблення окресленої проблеми вбачаємо в дослідженні спадкоємності наукових традицій i тематичної наступності в наукових розвідках учнів i послідовників наукової школи академіка А. Богуш.

\section{Література}

1. Варяниця Л. О. Дитяча субкультура як фактор соціалізації в молодшому дошкільному віці: автореф. дис. на здобуття наук. ступеня канд. пед. наук: спец. 13.00.05 «Соціальна педагогіка»/ Л. О. Варяниця; Луган. нац. ун-т ім. Тараса Шевченка. - Луганськ, 2005. - 20 с. 2. Водолага Н. В. Навчання розповідання дітей старшого дошкільного віку в театральній діяльності: автореф. дис. на здобуття наук. ступеня канд. пед. наук: спец. 13.00.02 «Теорія і методика навчання (українська мова)» / Н. В. Водолага; Південноукр. держ. пед. ун-т ім. К. Д. Ушинського. - О., 2001. - 20 с. 3. Вчені ЛНУ. Довідник. Гавриш Наталія Василівна (педагог, доктор педагогічних наук, професор) [Електронний ресурс]. - Режим доступу: http://lib.lnpu.edu.ua/ua/resource/bibliography/scientific_lnpu/Gavrish.html 4. Гавриш Н. В. Розвиток мовленнєвотворчої діяльності в дошкільному віці: автореф. дис. на здобуття наук. ступеня доктора пед. наук: спец. 13.00.02 «Теорія і методика 
навчання (українська мова)»/ Н. В. Гавриш. - К. : Національний педагогічний університет імені М. П. Драгоманова, 2002. - 40 с. 5. Гнізділова О. А. Наукові школи вищих педагогічних навчальних закладів Східної України XX століття: теорія, досвід, перспективи: [монографія] / О. А. Гнізділова // Полтавський нац. пед. ун-т імені В. Г. Короленка. - Полтава : Вид-во ПНПУ імені В. Г. Короленка, 2011. 388 с. 6. Курінна С. М. Особливості соціалізації дітей шести-семи років у різних умовах життєдіяльності: автореф. дис. на здобуття наук. ступеня канд. пед. наук: спец. 13.00.05 «Соціальна педагогіка»/ С. М. Курінна; Луганський національний педагогічний ун-т ім. Тараса Шевченка. - Луганськ, 2004. - 20 с. 7. Лопатіна Г. О. Методика навчання діалогічного мовлення дітей молодшого дошкільного віку: автореф. дис. на здобуття наук. ступеня канд. пед. наук: спец.13.00.02 «Теорія і методика навчання (українська мова)»/ Г. О. Лопатіна. - Луганськ, 2012. - 20 с. 8. Луганський національний універитет імені Тараса Шевченка. Кафедра дошкільної та початкової освіти / Кадровий склад кафедри [Електронний ресурс]. Режим доступу: http://www.luguniv.edu.ua/?z1=b,2500 9. Макаренко I. В. Соціальнопедагогічна підтримка батьків дітей раннього віку 3 особливими потребами: автореф. дис. на здобуття наук. ступеня канд. пед. наук: спец. 13.00.05 «Соціальна педагогіка» / I. В. Макаренко; Луган. нац. ун-т ім. Тараса Шевченка. - Луганськ, 2009. - 20 с. 10. Малахова О. В. Педагогічні умови соціалізації молодших школярів у стосунках з однолітками: автореф. дис. на здобуття наук. ступеня канд. пед. наук: спец. 13.00.05 «Соціальна педагогіка» / О. В. Малахова; Луган. нац. ун-т ім. Тараса Шевченка. - Луганськ, 2007. - 20 с. 11. Міністерство освіти і науки України. Офіційний веб-сайт [Електронний ресурс]. - Режим доступу: http:/www.mon.gov.ua/ua/regionalnews/18894-vitaemo-laureata-dergeavnoyi-premiyiukrayini-v-galuzi-osviti-2013-roku-gavrish-nataliyu-vasilivnu 12. Наукові школи Луганського національного університету імені Тараса Шевченка [Електронний peсурс]. - Режим доступу: http://www.luguniv.edu.ua/?zl=b,1826 13. Саприкіна О. В. Розвиток активного мовлення дітей третього року життя художньо-продуктивній діяльності: автореф. дис. на здобуття наук. ступеня канд. пед. наук: спец. 13.00.02 «Теорія і методика навчання (українська мова)»/ О. В. Саприкіна; Південноукр. держ. пед. ун-т ім. К.Д. Ушинського. - О., 2008. - 20 с.

УДК 378.147

Евгена Гордійчук

\section{ОСОБЛИВОСТІ СПІВПРАЦІ ВИЩИХ НАВЧАЛЬНИХ ЗАКЛАДІВ УКРАЇНИ ТА ПОЛЬЩІ В КОНТЕКСТІ СВРОІНТЕГРАЦЇ̈}

Гордійчук Є. С. Особливості співпраці вищих навчальних закладів України та Польщі в контексті євроінтеграції.

У статті розглядаються тенденції розвитку освітньої системи України в аспекті євроінтеграції освіти у контексті Болонської угоди. Досліджено особливості вищої професійної освіти Польщі та обгрунтовано важливість практичного використання вітчизняною професійною освітою прогресивного досвіду цієї країни.

Ключові слова: система професійної освіти, конкурентоспроможність, Болонський процес, європейський ринок праці. 